\title{
SYARIF HIDAYAT
}

\section{'Shadow State'? \\ Business and politics in the province of Banten}

\begin{abstract}
Our knowledge of the nature of local political leadership in modern democracies based on systematic comparative scholarship is limited. This makes it difficult to generalise across political systems. [...] Political scientists just have been more interested in their own political system, and in interviewing national politicians than in comparative studies of local leaders. (Eldersveld et al. 1995:1.)
\end{abstract}

The informal market role in rulers' construction of parallel political authority in the wake of the near total decay of formal state institutions - a Shadow State - is less well known. (William Reno 1995:1.)

\section{Introduction}

The quotations above indicate how few comprehensive studies there are on local politics. Observers tend to focus on the national level. Yet in the Indonesian context, local power relations cannot be understood simply through a formal approach, as they also involve informal networks, including relations between power holders and business. Therefore, a fuller understanding requires an approach that can simultaneously comprehend the formal and informal relations.

Motivated by a desire to understand more fully the power relations in the conduct of local governance in Indonesia, especially in the post-Suharto era, I decided to undertake this research, with the theme 'Business and politics in the province of Banten'. My interest grew when one day I found an article in the 'Nusantara' column of Kompas daily (4-7-2003), entitled 'If you're going to Banten, don't forget your black clothes'. The writer, 'Zal', described the influence of the jawara in the conduct of local government in Banten. ${ }^{1}$ The

1 Raffles (1965) and M. Williams (1990:45-6) define the jawara in Banten as people who do not have fixed jobs and commit criminal acts. I would further describe them as an individual or 


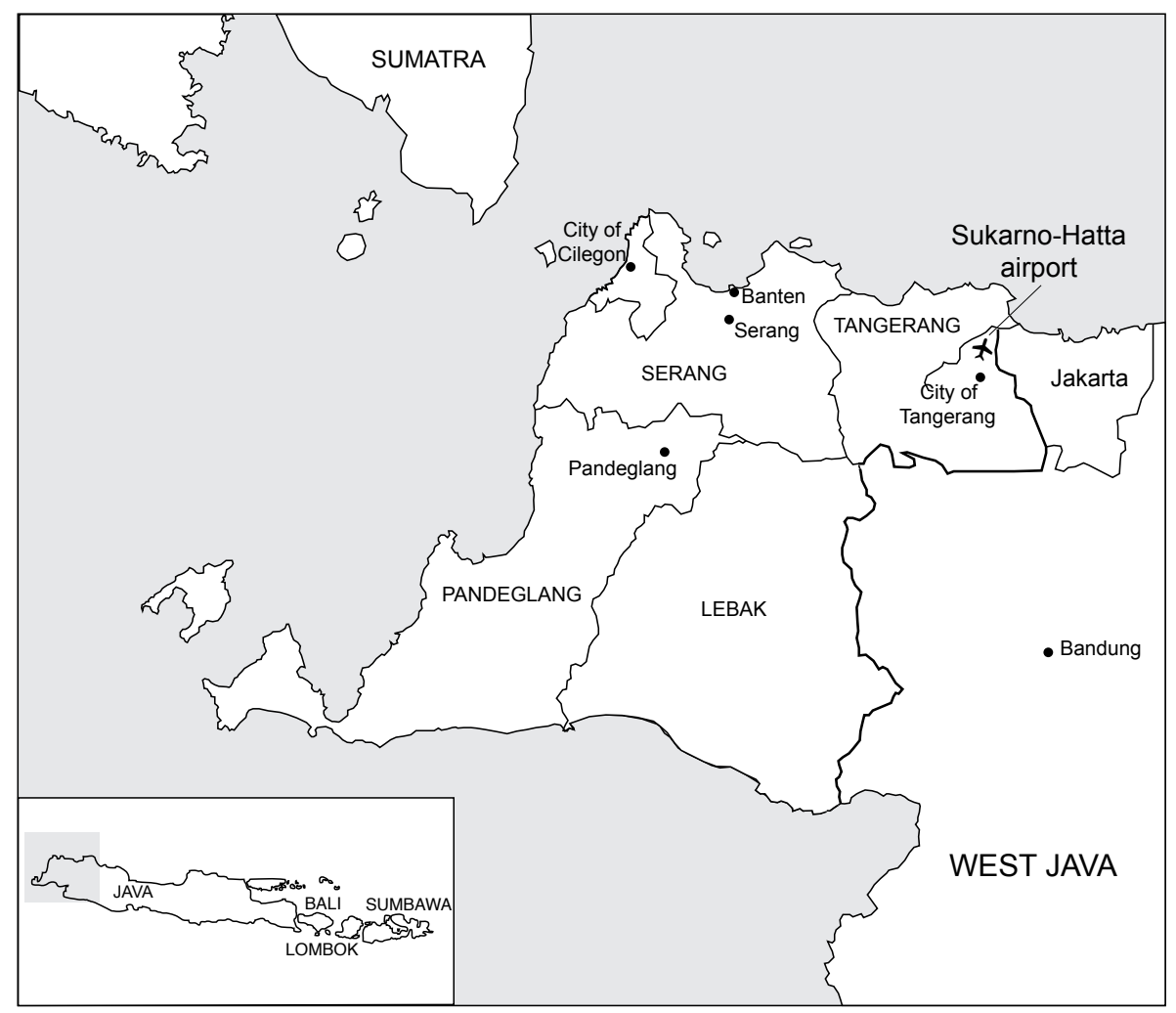

Map 8. Banten 
black clothes that he referred to are the official uniform of the jawara, now better known as pendekar. These black-clad pendekar, Zal wrote, have awesome power and influence. They control projects and intervene in local government policies:

Black clothes are the favourite of the Chief of Banten's pendekar, Chassan Sochib (74). Wherever he goes, this community figure always wears only black. Chassan has dozens of black garments. Banten's public considers him an important local personage and, indeed, an important actor in the province's history. Chassan is seen as having served the development of Banten's infrastructure through his numerous contracting companies. However, he is also often the object of public criticism; he is accused of excessive intervention in local government policy. 'Especially when it comes to projects, nearly all of them are controlled by the (group dressed in) black', says one Banten Provincial Government official.

Chassan denies these allegations. On several occasions Chassan has said that these misguided charges are simply due to jealousy. He claims that his contracting companies and the trust he has gained from the government are thanks to his many years of hard work.

It is undeniable that Chassan is considered a 'strong man' in Banten. Many national figures are known to be close to him, such as General (retired) Wiranto. It also happens that one of Chassan's daughters, Ratu Atut Chosiyah (39), was elected as Banten's first deputy governor, on a ticket with governor Djoko Munandar.

This journalistic information inspired me to examine the role of the jawara in Banten in its initial period as a separate province. Not all jawara in Banten are 'pure' jawara, who rely solely on their martial arts ability and their powers of invulnerability. Some are businessmen, with a tremendous interest in obtaining access to the resources controlled by the local government. They will make maximum use of this dual status. As businessmen, they will maximize their financial resources, and as jawara, they can use their resources of force.

The provisional suspicion of the existence of 'dual-status jawara' then inspired the writer to develop a number of questions: Is it true that the jawara in Banten also have status as business operators? If so, how great is their influence in the conduct of government in Banten? Is there a correlation between their role in the establishment of Banten province (especially in the election of governor and deputy governor) and their role in the post-election period? How was this access to the local government built? And how do these 'jawara-entrepreneurs' and local government officials interact?

group of persons who have a source of physical power (and the supernatural knowledge that accompanies it), who dare to oppose injustice, and who protect weaker individuals or community groups. 


\section{Historical background, social characteristics, and economic profile of Banten}

Banten is one of five new provinces established since the passage of Law no. 22/1999 and Law no. 25/1999. Banten was the first and opened the door for the creation of the other new provinces through partitioning of existing ones - Bangka Belitung, Gorontalo, North Maluku, and the Riau Islands. Banten had a long history as an autonomous region during the Sultanate (1552-1809). But during the Dutch colonial occupation, with the abolition of the Sultanate of Banten, the area lost its autonomy (in 1817). It became a Residency (Khatib Mansur 2001:531). With the enactment of Law no. 5/1974 on Government in the Regions, the Suharto regime reduced Banten to one of several regencies under the Province of West Java. This brought with it many disadvantages. Until the end of the New Order, Banten had West Java's lowest levels of education and public welfare. Banten also had a high number of 'backward villages' (Khatib Mansur 2001:166-7). All these things help explain the movement to establish a separate province of Banten, which apparently began in the late 1950s. ${ }^{2}$

After laying buried throughout the New Order, the will to establish a province resurfaced in early 1999. Numerous organizations were established. Three important ones were the Komite Pembentukan Propinsi Banten (KPPB, Committee for the Establishment of the Province of Banten) led by Uwes Qorny; Kelompok Kerja Pembentukan Propinsi Banten (Pokja PBB, the Working Group for the Establishment of the Province of Banten) led by H. Irsyad Djuwaeli; and Badan Koordinasi Pembentukan Propinsi Banten (BAKOR PBB, the Coordination Body for the Establishment of the Province of Banten) led by H.Tb. Tryana Sjam'un. Public figures and other elements of the community including jawara and entrepreneurs joined together, and strategies both formal and informal were put in play. The long journey of the people of Banten to achieve their ambition reached its climax on 4 October 2000, when the national parliament (Dewan Perwakilan Rakyat Republik Indonesia, DPR-RI) passed the Law on Establishment of the Province of Banten (Law no. 23/2000).

Moch. Aly Yahya was a key 'figure of struggle' who worked on many levels. As a 'son of Banten', he was a member of the steering committees of several of the organizations in the movement, including KPPB and BAKOR PPB. At the same time, as a young Golkar politician, he sat in the national parliament. It was in his capacity as a DPR-RI member that he drafted the

2 Interviews with Hasan Alayrus, 3-6-2004; Djamaludin, 18-6-2004; and UU Mangkusasmita, 1-7-2004. See also the 'Remarks from a Banten public figure' written by Kiyai-Haji Tubagus Chasan Sochib and the Prologue written by H. Uwes Qorny in the book by Khatib Mansur (2001). 
DPR Initiative Bill (Rencana Undang Undang, RUU) on Establishment of the Province of Banten, which was later passed as Law no. 23/2000.

The new province of Banten comprises four regencies and two cities: Serang, Pandeglang, Lebak, Tangerang, the City of Tangerang, and the City of Cilegon. Serang was designated the capital. One unique aspect of Banten is the harmonious relations between jawara and Ulama (religious leaders). In most people's understanding, Ulama and jawara are two diametrically opposed worlds; yet in Banten they live together in a harmonious synergy. It is therefore quite right when M. Tihami (a historian in Banten), says that 'Ulama and jawara in Banten have always worked hand in hand - since the period of the Sultanate, in the struggle to expel the colonialists, and in the period of Indonesian independence' ${ }^{3}$ Yet their roles have diverged in history (M. Williams 1990; Sartono Kartodirdjo 1966; Raffles 1965). The jawara have continued to play a dominant role as informal political force, from the time of the Sultanate to the present day, while the official role of the Ulama in the conduct of government affairs has all but disappeared.

Turning now to the economy, three main sectors play an important role. In 2000 the Gross Regional Domestic Product (GRDP) of Banten was divided as follows: $50.41 \%$ for the Processing Industry sector; $17.36 \%$ for the Trade, Hotel, and Restaurant sector; and $9.49 \%$ for the Agriculture sector, with several other smaller sectors. ${ }^{4}$ Thus, around $50 \%$ of Banten's economy is dominated by manufacturing, which includes textile, finished clothing and leather, chemicals, and metal goods. However, this does not position manufacturing as the main target of the government development programs. As a newly established province, over the past four years (2001-2004) most of the development programs in Banten have been geared toward upgrading economic infrastructure and basic services, especially in Education and Health. In 2001 the budget allocation for construction of roads/transportation facilities and other physical structures came to around Rp 116 billion (54.7\% of the total Regional Budget (Anggaran Pendapatan dan Belanja Daerah, APBD)). ${ }^{5}$ In 2002, this rose to Rp 130 billion (30\%), ${ }^{6}$ in 2003 to Rp 150 billion (34\%), ${ }^{7}$ and in 2004 to a phenomenal Rp 216 billion (49\%). ${ }^{8}$ The execution of these large-scale physical construction projects has become one of the main objects of attention from business people in their 'informal economy' practices with local government officials.

3 Interview, 24-6-2004.

4 Badan Perencanaan Daerah Propinsi Banten 2002. Similar figures can be read for the years 2001 through 2003 (Badan Perencanaan Daerah Propinsi Banten 2003).

5 Results of Discussion of Bill on Revision of the Banten Provincial Budget, 2001.

6 Banten Provincial Regulation no. 37/2002 on Revision of Banten Provincial Budget for 2002.

7 Banten Provincial Regulation no. 10/2003 on Revision of Banten Provincial Budget for 2003.

8 Banten Provincial Regulation no. 3/2004 on Revision of Banten Provincial Budget for 2004. 
'Jawara-entrepreneurs' is one of the terms popularly used among observers in Banten to label those businessmen, whether individuals or groups, who now have such a dominant influence over the provincial government's top officials. ' 'Tuan Besar', who will be the chief protagonist in this study, is an important figure in this jawara-entrepreneur network. ${ }^{10} \mathrm{He}$ has been a businessman of the first rank, especially in construction, since the 1980s. Before Banten became a province, Tuan Besar had many dealings with the West Java Provincial Government and was frequently entrusted to handle large-scale construction projects. At the same time, Tuan Besar's status as a prominent jawara is another, but inseparable, side of his identity. This status is not simply hereditary; for he was the founder of one of Banten's foremost jawara organizations. Tuan Besar is also a senior politician in Golkar.

Formal and informal governance: empirical reality and the approach of this study in Banten

As soon as Banten was established as a province, several steps were taken to complete its formal government apparatus. In early March 2001, the Panitia Pengisian Keanggotaan (PPK, Committee to Select the Membership) of the Banten Dewan Perwakilan Rakyat Daerah (DPRD, Provincial Parliament) was established, under the chairmanship of Hasan Alaydrus. ${ }^{11}$ This committee, later known simply as the Banten PPK-DPRD, or the Team of Five, was appointed by the Minister of the Interior in Jakarta. The team's main duties were to determine the numbers of seats attained by each political party in the provincial DPRD, based on the results of the June 1999 election; to draft, establish, and announce the Daftar Calon Sementara Baru (DCSB, Provisional List of New Candidates); to accommodate and follow up on public objections to the DCSB; to draft, establish, and announce the Daftar Calon Tetap Baru (DCTB, Definitive List of New Candidates); and finally, to designate the selected candidates. The PPK-DPRD worked quickly. Less than a week after it was established, the PPK-DPRD had set out its working agenda (Agus Sutisna 2001:48). By July 2001, only two months later, it had completed the

9 This information was obtained from interviews with Iwan Kusuma Hamdan, 1-6-2004 and Boyke Pribadi, 7-6-2004, among others.

10 Tuan Besar is a nickname I am using to protect his privacy. Tuan is an honorific term of address roughly equivalent to sir, boss or master, while besar, literally 'big', indicates his influence.

11 The establishment of the Committee to Select the Membership of the Provincial DPRD was stipulated through Decree of the Minister of the Interior no. 162-35/2001 dated 2 March 2001. Hasan Alaydrus, who was appointed as the Committee's Chairman, was a leading figure in the struggle to establish the province of Banten. 
last item on its agenda, the selection of the definitive candidates for members of the Banten provincial DPRD. ${ }^{12}$ The Banten provincial DPRD has 75 seats, but 8 were allocated to the military (Tentara Nasional Indonesia, TNI) and police (Kepolisian Republik Indonesia, Polri). Thus, the total number of seats to be allocated among the political parties was only 67 .

The Banten provincial DPRD for the 2001-2004 term was headed by Dharmono K. Lawi (Chairman), a politician from Partai Demokrasi Indonesia Perjuangan (PDI-P, the Indonesian Democratic Party of Struggle). The three deputy Chairmen were Muslim Jamaluddin (Golkar), Infantry Col. Rohman (Tentara Nasional Indonesia - Angkatan Darat, TNI-AD, the Indonesian National Army - Ground Forces), and Mufrodi Muchsin (PPP, Partai Persatuan Pembangunan, United Development Party). ${ }^{13}$ Thus the DPRD was dominated by three major political parties: PDI-P, Golkar, and PPP. Of the 67 seats, 24 seats were held by PDI-P, 12 by Golkar, and 12 by PPP. The DPRD was not dominated by one party. In such a situation, it was virtually unavoidable that informal practices such as lobbying and compromises would colour decision-making processes.

The next step, and the first duty of the DPRD, was to elect the governor and deputy governor for the 2001-2006 term. The election process began on 16 September 2001 and ended on 3 December 2001, when the ticket of Djoko Munandar and Ratu Atut Chosiyah was elected as the winner.

Djoko Munandar is a native of Solo, Central Java. His most recent position was deputy mayor of Cilegon. When he registered as a prospective candidate for governor of Banten, Djoko allied himself with the PPP. Ratu Atut Chosiyah is a businesswoman from Serang and daughter of Kyai Haji Tubagus Chassan Sochib. ${ }^{14}$ Atut was nominated for deputy governor of Banten by Golkar.

The institutional apparatus was now complete. Hopes for the immediate creation of a more prosperous, democratic, and religious Banten were concentrated on these two important provincial institutions, and particularly on the newly-elected governor and deputy governor. Similar hopes at first accompanied me when I began my research in Banten in April 2004 (three months after Banten was established). But during the first two months I was surprised by the attitudes of a majority of the informants, who tended to be

12 The chronology and dynamics of the process of selecting the membership of the Banten Provincial DPRD are described in detail in Agus Sutisna (2001:43-54).

13 Decree of the Minister of the Interior no. 161/2001 dated 24 August 2001 on Inauguration of the Leadership of the Banten Provincial People's Representative Assembly.

14 Chairman of the Indonesian Association of Champions of Banten Martial Arts, Art and Culture, Persatuan Pendekar Persilatan dan Seni Budaya Banten Indonesia, PPPSBBI; senior politician in the Golkar Party; and Chairman of the Banten Chamber of Commerce and Industry (Kamar Dagang Indonesia, Kadin) (Iwan Kusuma Hamdan et al. 2004). 
pessimistic when evaluating the performance of the provincial government, and seemed unenthusiastic about the future.

Several of my informants said the provincial government was almost 'totally crippled' in carrying out its formal functions, because informal forces were able to control the governor. ${ }^{15} \mathrm{HOS}$, a member of the provincial DPRD, said Banten had a sort of 'private government' headed by the Tuan Besar mentioned previously.16 This private government had tremendous influence over the provincial government's economic dealings. He alleged it monopolized nearly all local government projects, and pressured the provincial government to accommodate its interests when drafting the annual project development budget. Even more interesting information was put forward by BOB, an academic at Tirtayasa University. ${ }^{17}$ Agreeing with HOS, he also described informal practices within the local bureaucracy. BOB tried to persuade me of Tuan Besar's power in determining bureaucratic transfers. Ayip Muchfi was the first district secretary (sekretaris daerah, sekda) of the Province of Banten. He was appointed immediately after Hakamudin Jamal was appointed acting governor of Banten. But once Djoko Munandar and Atut Chosiyah became governor and deputy governor, Ayip was dismissed, without going through the proper procedure. Apparently, BOB continued, the replacement of the regional secretary was related to a long-standing personal conflict between Ayip and Tuan Besar.

The initial indications suggest that informal political and economic forces dominate local governance in Banten. In studies of state-society relations, such practices of informal governance, or Shadow States, are nothing new. In the Indonesian context there have been few critical analyses of Shadow State practices. But Henk Schulte Nordholt $(2003: 558,579)$ explicitly mentioned Shadow State practices in connection with the decentralization and regional autonomy policies in the post-Suharto period:

New ways of looking at 'the state' are necessary in order to trace continuities in patrimonial patterns and to incorporate various arrangements that link formal institutions with informal networks, which help to undermine artificial distinctions between 'state', 'society', and 'market'. [...] Decentralization in Indonesia does not necessarily result in democratization, good governance, and the strengthening of civil society at the regional level. Instead, we witness a decentralization of corruption, collusion, and political violence that once belonged to the centralized regime of the New Order but is now moulded in existing patrimonial patterns at the regional level. [...] On the whole, regional leadership may take the shape

15 Among the informants interviewed were HKI (academic and NGO activist), 1-5-2004; MUM (member of the Banten Provincial DPRD), 30-5-2004; TNT (high Serang Regency official) 14-5-2004; and MAA (Banten journalist), 15-5-2004.

16 HOS is a member of the Banten Provincial DPRD. Interview, 9-5-2004.

17 Interview with BOB, 7-5-2004. 
of what John Sidel (1999) has called bossism, which operates in regional shadow regimes characterized by alliances of bureaucrats, party bosses, businesspeople, military, and criminals.

Barbara Harriss-White has provided a more comprehensive theoretical and empirical discussion about the informal economy and Shadow State practices in India. According to Harriss-White, there are at least two definitions for the term 'informal economy'. First, business activities of an individual, and/or of a company not registered with the government, for which taxes are not paid. Second, the behaviour of formal institutions (public or private) to evade regulatory control. The forms of this second type of informal economy include tax exemptions, abuse of public policy, corruption, collusion, and forced privatization of state assets (Harriss-White 2003:4-6). It is clear that the first type of informal economy is the arena of 'the little guys' (small farmers and small business operators), while the second is the domain of 'the big guys' (large-scale business operators and state officials).

Barbara Harriss-White has applied an approach called 'social structure of accumulation' (SSA), in which social structures are one of the determinant factors for economic accumulation. She identified four such dimensions of social structure: class, caste, gender, and space. A majority of economic transactions in India take place through the informal economy. They proceed in a familial atmosphere, based more on reputation than on formal law, but also often with elements of (the threat of) violence:

Some roles in the 'shadow' state are played simultaneously by the bureaucrats of the official state; for instance, accepting tribute, patronage and/or clientelage. Other 'shadow' state livelihoods are a form of self employment, although they depend on state employees, politicians and other interested social forces for their incomes; for example, private armies enforcing black or corrupt contracts, intermediaries, technical fixers, gatekeepers, adjudicators of disputes, confidants, contractors and consultants. Hence the real state, including its shadow, is bigger than the formal state, and has a vested interest in the perpetuation of a stricken and porous formal state [...] By the end of the 1990s in some parts of India, notably Bihar, up to 40 percent of the development budget was said to be creamed off by contractors. The 'shadow' state spills spatially into the lanes surrounding state offices and into the private (some would argue, the 'female') domestic space of officials' residences. This must be the most vivid image of the blurred boundaries between state and society. (Harriss-White 2003:89.)

We can note four general characteristics of the practices of the informal market and the Shadow State. First, they develop as a consequence of the decay of the formal (state) institutions, especially when accompanied by an acute economic crisis. Second, accumulation of short-term political and economic benefits outside the framework of formal regulations is the primary aim of 
transactions through the informal market. Each party maximizes its resources to then trade on them in the informal market. Third, the modus operandi, or working mechanisms, of the informal market and the Shadow State fall into two categories: manipulation of public policy, and use of networks of individual alliances or institutional alliances. Fourth, the actors involved come from both the state and society. Among the latter H. Schulte Nordholt (2003) mentions business operators, party politicians, and even criminal gangs.

This approach is relevant for 'reading' the practices of local governance in Banten. The following section will describe the election of the governor and deputy governor, followed by a discussion of the practices of the 'Informal Government'.

\section{The election of the governor and deputy governor}

The process of electing the governor and deputy governor revealed the various social, economic, and political forces (especially the jawara businessmen) at work. This was obviously an important moment for them.

Several Banten community figures who had earlier been the main players in the struggle to establish the province of Banten disappeared during the election process. Among them were Tryana Sjam'un (Chairman of BAKOR PPB), Uwes Qorni (a pioneer in the movement to establish a province of Banten, and Chairman of KPPB), and Moch. Ali Yahya (drafter and proposer of the DPR Initiative Bill on Establishment of the Province of Banten). In contrast, the previously discussed Tuan Besar (a jawara-businessman figure), who during the period of the struggle to establish the province of Banten had played mostly a behind-the-scenes role, emerged as a dominant force.

In technical terms, the election of governor and deputy governor of Banten comprised five stages: initial registration of prospective candidates; screening of prospective candidates, stage I; screening stage II; selection of the definitive tickets of candidates for governor and deputy governor; and finally, the election of the ticket of governor and deputy governor ('D-day').

Initial registration of prospective candidates for governor and deputy governor

The initial registration of prospective candidates for governor and deputy governor began on 16 September 2001. The local political dynamics from the opening of registration to D-day - the election of the ticket of governor and deputy governor - were unpredictable. PDI-P nominated Mamas Chaeruddin (Chairman of the Banten DPD-PDI-P) as its candidate for governor. Golkar put forward Moch. Aly Yahya (member of the Golkar Faction in the DPR$\mathrm{RI}$ ) as its candidate for governor and Hj. Ratu Atut Chosiyah (a business- 
woman) for deputy governor. PPP nominated Djoko Munandar (Chairman of PPP's Banten Regional Leadership Board) as its candidate for governor. In addition, an alliance of three other parties - the Partai Keadilan (PK, Justice Party), the Partai Amanat Nasional (PAN, National Mandate Party) and the Partai Bulan Bintang (PBB, Moon and Star Party) nominated Tryana Sjam'un (businessman and figure in the struggle for the province of Banten) as their candidate for governor (Iwan Kusuma Hamdan et al. 2004:119-20).

Tuan Besar was not among the prospective candidates. This was part of the game-winning strategy. Rumours had long been spreading that Tuan Besar had ambitions to hold the post of 'Banten Number One' (governor). ${ }^{18}$ To disprove this rumour, Tuan Besar did not formally register as a prospective candidate for governor. However, behind the scenes, he had mobilized his resources behind a certain ticket of candidates. As a senior figure in the Banten Golkar Party, Tuan Besar had a clear obligation to support its candidates for governor (Moch. Aly Yahya) and deputy governor (Atut Chosiyah). But he had an even greater interest in ensuring the nomination of Atut, as Tuan Besar and Atut share a very close family relationship.

Little 'money politics' activity was going on at this early stage. But various community elements came out in favour of this or that candidate. A 'Letter of Support' for Atut Chosiyah came from the martial arts association Persatuan Pendekar Persilatan dan Seni Budaya Banten Indonesia (PPPSBBI, Indonesian Association of Champions of Banten Martial Arts) on 18 September 2001 (two days after the opening of registration of prospective candidates for governor and deputy governor). It was signed by the Chairman of PPPSBBI, H.Tb. Chasan Sochib, and its deputy secretary-general, M. Suminta Idris, ${ }^{19}$

We of the Executive Committee of the Indonesian Association of Champions of Banten Martial Arts, Art and Culture (PPPSBBI), in connection with the Election of the governor and deputy governor of the Province of Banten for the period 2001-2006, feel called [to declare that] it is necessary to select the right leaders, who understand the character and culture of Banten's society and have a sense of the unity and integrity of the people of Banten.

Therefore, we of the PPPSBBI herewith declare our full support for Mrs. $\mathrm{Hj}$. Ratu Atut Chosiyah as candidate for deputy governor of the Province of Banten for the period 2001-2006 in the coming election for governor and deputy governor.

The letter signalled that the jawara sided with Atut Chosiyah as candidate for deputy governor, and therefore also with whoever would be the candidate for governor on the same ticket with her. And it reflected an initial form of the jawara's involvement in the election process. Later, their involvement tended 
towards mass mobilization with the theme of 'protecting and safeguarding' the election, and towards intimidating supporters of other candidates. There are indications that these activities of the jawara were closely related to Tuan Besar's winning strategy. ${ }^{20}$

\section{Screening of candidates}

The first round had resulted in 22 prospective candidates for governor and 7 for deputy governor. These were now 'screened' to produce 12 candidates for governor and deputy governor of Banten. Up to this stage, the candidates were not yet assigned to pairs, or tickets. In the third round, screening stage II, the 12 candidates were paired up into 'tickets', each ticket being nominated by one of the 6 factions in the Banten Provincial DPRD. In its plenary session on 25 September 2001, through a secret vote, the DPRD designated 12 candidates for governor and deputy governor. ${ }^{21}$ In the next stage of screening, the factions in the Banten Provincial DPRD nominated 5 tickets of candidates for governor and deputy governor (Iwan Kusuma Hamdan et al. 2004:122). These 5 tickets were: 1 . Djoko Munandar and Ratu Atut Chosiyah (nominated by the Golkar and PPP Factions); 2. Herman Haeruman and Tb. Mamas Chaerudin (nominated by the PDI-P Faction); 3. Ace Suhaedi Madsupi and Tb. Mamas Chaerudin, nominated by the ABK Faction (Fraksi Amanat Bintang Keadilan, Mandate-Star-Justice Faction); 4. Herman Haeruman and Hilman Indra (nominated by the ABK Faction); and 5. Herman Haeruman and Ade Sudirman (nominated by the Al Bantani Faction).

The most striking point to note is the disappearance of Moch. Aly Yahya as candidate for governor during screening stage II. This prominent figure in the struggle to establish the province had received only 28 votes in screening stage I. But there are also strong indications that the disappearance of Yahya's name from the 'market' of candidates was closely related to the political scenario crafted by Tuan Besar and his 'Success Team'. As explained by several informants, from the outset Tuan Besar had a greater interest in the position of 'Banten II' (deputy governor), as this was the position relevant to Atut

20 Interviews with HKI (academic and NGO activist), 1-6-2004; MAA (Banten journalist), 156-2004; and HOS (member of Banten Provincial DPRD), 9-6-2004.

21 Harian Banten 26-9-2001. The 12 candidates for governor were Herman Saerens Sudiro (53 votes), H.M. Ali Muchtar (45 votes), Endjat Sudrajat (42 votes), H. Ace Suhaedi Madsupi (56 votes), Sagaf Usman (54 votes), Prof Dr Herman Haeruman (53 votes), Azril Azhari (47 votes), Susila Budi Mufreni (50 votes), M. Wasal Falah (37 votes), H. Suhaemi (52 votes), H.M. Aly Yahya (28 votes), and Djoko Munandar (54 votes), while the 12 candidates for deputy governor were Tri Mulyono (62 votes), H. Ade Sudirman (55 votes), H. Abdul Halim Amir (48 votes), Hj. Ratu Atut Chosiyah (61 votes), H.M. Masduki (50 votes), H. Djakaria Mahmud (43 votes), Gusti Bagja Mulyadi (53 votes), Tb. Mamas Chaerudin (42 votes), H. Makmun Suchari (51 votes), Mukhlisin Arief (45 votes), H.M. Sofwat Hadi (50 votes), and Hilman Indra (56 votes). 
Chosiyah, whom he was championing. The position of governor was too 'heavy' for Atut;'22 too heavy in terms of her own experience and personal capability, and too heavy for Golkar, which hoped to effect her victory. ${ }^{23}$ Yet Golkar had already nominated Aly Yahya for governor and Atut Chosiyah for deputy governor. To resolve this problem, things were 'arranged' so that Golkar decided only to seek the position of deputy governor. This was clearly one reason for Aly Yahya's withdrawal from the race, since from the start he was only interested in being nominated for governor. ${ }^{24}$

The challenge for Golkar, and for Tuan Besar, was to choose another candidate for governor to be paired with Atut Chosiyah. This was a complex job, which required heavy political and economic 'ammunition', as nearly all the candidates for governor who had passed through screening stage I already had partners to run for deputy governor. But in this situation they displayed their skills. After careful calculation, it was decided that Golkar must form a coalition with one or more other parties. The choice was between PPP and PDI-P. PPP had not yet determined the name of its candidate for deputy governor to be paired with Djoko Munandar (its candidate for governor). After various approaches and compromises, a Golkar-PPP coalition was formed, and the PPP's candidate for governor, Djoko Munandar, was paired with Ratu Atut Chosiyah as candidate for deputy governor. ${ }^{25}$ It appears that Tuan Besar was the main contributor to finance the election of this ticket. ${ }^{26}$

\section{Selection of the tickets of candidates}

The next stage was to determine the three tickets of candidates who would run in the final round, the election itself. On 3 October 2001 the three tickets selected were: 1. Djoko Munandar and Atut Chosiyah (nominated by PPP and Golkar); 2. Ace Suhaedi Madsupi and Tb. Mamas Chaerudin (nominated by PDI-P); and 3. Herman Haeruman and Ade Sudirman (Al Bantani Faction) (see Iwan Kusuma Hamdan et al. 2004:122). The selection of these three tickets of candidates elicited both positive and negative reactions from the public. For example, on the day after the three tickets were selected the

\footnotetext{
22 Interviews with HAI, 6-7-2004; HKI, 1-6-2004; and THA, 24-6-2004.

23 As explained in the earlier discussion, the Golkar Party had only 12 of the 75 seats in the Banten Provincial DPRD.

24 This decision by the Banten Golkar Party DPD was acknowledged by Aly Yahya when this writer interviewed him. When asked about his feelings regarding the Golkar DPD's decision, Aly Yahya diplomatically stated, 'as a good senior Golkar Party cadre, I had to respect and abide by the DPD's decision' (interview, 6-7-2004).

25 This information was obtained from an interview with HAI, 6-7-2004.

26 This information was obtained from interviews with several informants, including SME (business operator), 9-6-2004; THA (former BAKOR officer), 24-6-2004; HKI, 13-6-2004; BOB (academic), 7-6-2004; and MAA, 15-6-2004.
} 
NGO Aliansi Martabat Perempuan Banten (AMPB, Alliance for the Dignity of Banten Women) submitted a letter rejecting the candidacy of Atut Chosiyah for deputy governor of Banten. Signed by Hj. Ratu Syarifa Usmah Wahid (Chairwoman) and addressed to the members of the Banten Provincial DPRD, it said:

The presence of the name of Ratu Atut Chosiyah among the candidates for governor and deputy governor of Banten for 2001-2006 is deeply shocking and disappointing to the Alliance for the Dignity of Banten Women. This woman named Ratu Atut Chosiyah is extremely depraved in terms of her morality and behaviour, and unsuited to represent the women of Banten.

In our opinion, Ratu Atut Chosiyah is totally unsuited to represent women in this honoured position in the province of Banten. Ratu Atut Chosiayah is well known primarily as a businesswoman who will use any means to promote the success of her businesses. She is shamelessly having affairs with those she plans to do business with, [...]. Among those who work in the Public Works Service in Bandung, she is very well known. [...]

Therefore, we as the Board and the members of the Alliance for the Dignity of Banten Women herewith 'reject the candidacy of Ratu Atut Chosiyah for deputy governor of Banten'. ${ }^{27}$

The next day (5 October 2001), Perguruan Paku Jung Kulon, a martial arts school in South Banten, responded with a letter of support for Atut Chosiyah's candidacy. This letter, signed by M. Suwarta SMHK (Chairman) and addressed to the Chairmen of the Factions in the Banten Provincial DPRD, said:

We, from the Community Organization 'Perguruan Paku Jung Kulon' of South Banten, in selecting a candidate for deputy governor of the Province of Banten for the period 2001-2006, follow the call of our hearts in supporting Mrs Hj. Ratu Atut Chosiyah, the daughter of a great Banten personage, as the partner for the governor soon to be elected.

Our reasons for choosing Mrs Hj. Ratu Atut Chosiyah, daughter of this great Banten figure, for deputy governor of Banten are as follows: She is known by the community of Banten; She has extensive understanding of the region and culture of Banten [...]. She has experience in the administrative technicalities of development in and community activities, as a successful national-scale business operator; [...]. She is the one and only 'Srikandi of Banten' who wishes to improve the role of women in the various aspects of development. ${ }^{28}$

27 This statement of rejection is quoted from Statement of the Alliance for the Dignity of Banten Women no. 66/AMPB/X/01, 4-10-2001 (the writer has a photocopy of the letter).

28 This statement of support is excerpted from letter of 'Perguruan Paku Jung Kulon' no. 01/PPJBS/2001, 5 October 2001, regarding Support for deputy governor Candidate Hj. Rt. Atut Chosiyah (the writer has a photocopy of this letter). 


\section{Postponement of the election}

The waves of support and rejection continued to swell and became increasingly difficult to hold back. Although the DPRD tried to fend off the various demands, protests, and statements of rejection submitted by various elements of the Banten community, it was difficult to cover up the deviations that had occurred in the process. According to Law no. 22/1999 and Government Regulation no. 151/2000, the pairing of candidates for governor and deputy governor should have been done by the candidates themselves, and not by the DPRD factions as had happened here. Another violation had to do with the administrative requirements of $\mathrm{Tb}$. Mamas Chaerudin, the candidate for deputy governor who was paired with Ace Suhaedi Madsupi; it was suspected that he did not actually have a high school diploma or the equivalent, as required by Law no. 22/1999 and Government Regulation no. 151/2000 (Iwan Kusuma Hamdan et al. 2004:122).

To resolve these problems, the Banten Provincial DPRD consulted the Department of the Interior, which felt that the rules used in Banten were in need of correction. So on 12 November 2001 the DPRD held a plenary session to discuss revision of the rules of order for election of the governor and deputy governor. ${ }^{29}$ The results of this revision were then submitted to the Department of the Interior for review, and at the same time, informal approaches were undertaken to complement this. It is reported by one member of the Banten Provincial DPRD that Tuan Besar took part in this informal political process by making the most of his personal relationship with the Minister of the Interior. ${ }^{30}$ On 24 November 2001 the Minister of the Interior, Hari Sabarno, sent a letter of approval. ${ }^{31}$ Consequently a meeting of the Steering Committee (Panitia Musyawarah, Panmus) of the Banten DPRD decided on 26 November 2001 that the final round, the election of the governor and deputy governor of Banten, would be held on 3 December 2001.

\section{'D-day': election of the governor and deputy governor}

The long-awaited day finally arrived. The atmosphere was increasingly tense, because even though the DPRD had granted full authority to the police and military to handle security for the election session, and asked them to clear the area within a 4-kilometre radius of the DPRD building of jawara, this ele-

29 Invitation Letter of the Banten Provincial DPRD (signed by H. Muslim Jamaluddin), no. 162.4/DPRD/157/X/2001, dated 9-11-2001, regarding plenary session.

30 Interview, 9-6-2004.

31 Letter from the Minister of the Interior to the Chairman of the Banten Provincial DPRD, no. 121/2402/SJ dated 24-11-2001 (the writer has a photocopy of this letter). 
ment of the community continued to mobilize its masses. The jawara, wrote Iwan Kusuma Hamdan et al. (2004:126), were on guard as early as 06.00 a.m., claiming to safeguard the election process. They were even swarming inside the building in regular civilian clothing. ${ }^{32}$ In this rather tense atmosphere, the DPRD held the final election round. Sixty-nine of the 75 assembly members were present. After a vote by secret ballot, the final count showed that the ticket of Djoko Munandar and Atut Chosiyah had emerged as the winners, with 37 votes (Iwan Kusuma Hamdan et al. 2004:126). Apparently, ${ }^{33}$ the defeat of the PDI-P ticket was due not only to money politics and intimidation but also to political compromises between the Golkar Party and the PDI-P to allocate the leadership positions in the regional legislature and executive. It must be remembered that the Chairman of the Banten Provincial DPRD, Dharmono K. Lawi, was from the PDI-P.

Among those who were most pleased and able to breathe a sigh of relief after this final round of the election were Tuan Besar and his Success Team. After navigating a highly complex election process that took up great political and economic resources, finally their candidates had achieved victory. The next question was how Tuan Besar would now be compensated for the political and economic 'sweat' expended in the electoral process.

\section{Tuan Besar and practices of informal government: the case of project racketeering}

As briefly described in the previous discussion, the cases of 'project racketeering' (premanisme proyek) had their roots in the monopolistic practices in the execution of physical infrastructure projects for the Banten provincial government during fiscal year 2003. From the information written in the Dokumen Anggaran Satuan Kerja (DASK, Work Unit Budget Document) of Banten's regional budget (Anggaran Pendapatan dan Belanja Daerah, APBD), it is known that the total value of the construction budget for Banten in fiscal year 2003, both that financed from the APBD and from the state budget (Anggaran Pendapatan Belanja Negara, APBN), was approximately Rp 35 billion. ${ }^{34}$ From this budget, the Banten provincial government financed numerous physical and non-physical development projects. According to Presidential Decree (Keputusan Presiden, Keppres) no. 18/2000 on Guidelines for Procurement of Goods and Services for Government Agencies, specifi-

\footnotetext{
32 Interview with HOS, 18-6-2004.

33 Interviews with HKI, 1-5-2004, and HOS, 9-5-2004.

34 Decree of the governor Banten no. 902/Kep 45-Hak/2003, on Determination of the Work Unit Budget Document (DASK) of the Banten Provincial Budget (APBD). The writer has a photocopy of this document.
} 
cally in Article 12(2), procurement of contracting goods/services and other services shall be done through:

a. Tender, that is, a series of activities to supply the needed goods/services by creating healthy competition among equal suppliers of goods/services that meet the requirements, based on certain established methods and procedures that are consistently followed by the parties concerned, so that the best supplier is selected.

b. Direct selection, if the Tender method is difficult to implement, or will not ensure achievement of the target. [Direct selection] is done by comparing the bids from several qualified suppliers of goods/services through price quotations, or technical and price quotations, followed by competitive negotiations, both on technical aspects and on price, to obtain a reasonable and technically justifiable price.

Indeed in formal terms nearly all the Banten provincial government's development projects during fiscal year 2003 were implemented through tender. However, as indicated by HOS, ${ }^{35}$ many of these tenders were simply formalities to comply with the administrative procedures. In reality, HOS continued, the tender winner had already been determined. Tuan Besar played an important role in influencing the Tender Committee and other important personages. His modus operandi varied from informal lobbying with local officials and distribution of 'envelopes' (bribes), to physical intimidation. It is difficult to know the precise value of the projects managed directly by Tuan Besar. He owns several companies not registered in his name, and often uses other companies that he does not own as a strategy for winning tenders. Even so, as HOS pointed out, in general Tuan Besar is interested mostly in physical construction projects. Tuan Besar is among the top entrepreneurs in the lucrative construction sector. In 2003 the total value of physical development and/or construction projects was approximately Rp 18 billion (51.4\% of the province's total development budget for that year). ${ }^{36}$ Most of these projects were concentrated in six institutions that carry out local government projects: Dinas Bina Marga (road and highway construction and maintenance, around Rp 3 billion); ${ }^{37}$ Dinas Cipta Karya (housing, building, and urban development, around Rp 4 billion); ${ }^{38}$ the

35 Interview with HOS, 9-5-2004.

36 Decree of the governor Banten no. 902/Kep 45-Hak/2003, on Determination of the Work Unit Budget Document (DASK) of the Banten Provincial Budget (APBD), Books 1, 2, and 3. The writer has photocopies of these documents.

37 Road and Bridge Supervision Projects, and Road and Bridge Planning Projects.

38 Project for Design of the Education and Training Campus of the Province of Banten, Project for Technical Design of Banten Provincial Government Administrative Buildings, Project for 
Irrigation Service (around Rp 2.5 billion); ${ }^{39}$ the Health Service (around Rp 430 million); 40 the General Services Bureau (around Rp 4.6 billion); ${ }^{41}$ and the Equipment Bureau (around Rp 2 billion). 42

It seems competitors for Tuan Besar were burdened with an extra fee. For projects not performed by Tuan Besar himself or allocated to business operators in his group, a project fee of $10 \%$ to $11 \%$ of the project value was levied. The percentages of these project fees, by category of activity and source of financing, can be seen in the following table:

Project fees by category of activity and source of funds

Project classification

Project fees by source of funds (\%)

\begin{tabular}{lrr}
\cline { 2 - 3 } & APBD & APBN \\
\hline Road and highway projects & 10 & 11 \\
Irrigation projects & 11 & 11 \\
Building construction projects & 10 & 10 \\
Procurement projects & 10 & 10 \\
\hline
\end{tabular}

Source: This information is quoted from a circular letter sent on 12 April 2002 to a business operator who was to perform a project with classification K-1.

How did the issue of 'project racketeering' come to the fore? According to information from several DPRD members who were interviewed, ${ }^{43}$ suspicions of malpractice in the management of Banten provincial government projects first arose with an official report from the Badan Pemeriksaan Keuangan (BPK, Supreme Audit Agency) to the Chairman of the DPR-RI on 19 February 2003, which stated:

\footnotetext{
Housing and Residential Accommodation Development in the Province of Banten (P2P), Project for Development of Residential Facilities and Infrastructure (Technical Assistance for Guidance of Construction).

39 Project to Supervise Execution of the Work of Projects for River Rehabilitation and Normalization Projects, Irrigation Network Projects, and Lakes Overlapping Regency/City Boundaries, Project for Technical Planning of Execution of Pond Construction Projects, Rural Unfiltered Water Cistern Projects, and Water Resource Planning Projects.

40 Project for the Establishment of Malingping Hospital.

41 Project for Rehabilitation of State Buildings, Expansion of General Services Bureau Offices, Employee Offices, Government Bureaus, Rejuvenation and Upgrading of Parks, and Utilization of Bus Parking Areas at the Regional Secretariats; and Project for Facility and Infrastructure Upgrading, 2004.

42 Project for Development of Dormitory Support Infrastructure.

43 Interview with HOS, 9-5-2004.
} 
The results of the audit revealed 14 findings with a value of Rp 24,207.67 million for Fiscal Year 2002 (through October), which are categorized into indications of losses to the region/state of Rp 5,497.46 million, reduction to regional/ state revenues of $\operatorname{Rp} 333.33$ million, wastage of $R p 10,191.02$ million, [in]effectiveness of Rp 8,09.81 million, and others in the amount of Rp 94.05 million (Audit document for the second semester of Fiscal Year 2002, pages 1-2).

The preliminary suspicions of practices of project racketeering then surfaced on 26 August 2003, when the Fraksi Amanat Bintang Keadilan (ABK, Mandate-Star-Justice Faction) of the Banten Provincial DPRD submitted a Faction's Final Note in response to the governor's Financial Note on revision of the Regional Budget for 2003. In presenting the ABK Faction's Final Note, the faction leader said:

We would also like to express our thanks to all members of the Banten community, as we all share the same perceptions regarding project racketeering. Only by tearing out this loathsome practice by its roots can our beloved province's journey toward development proceed as desired. As long as this project racketeering behaviour persists, no matter how great the budget that is allocated to develop our beloved province, the results will never reach the target. The people of Banten will never be able to enjoy true progress and prosperity.

These project racketeering practices are a form of corruption, collusion, and nepotism (korupsi, kolusi, nepotisme, KKN), and eradicating them must be the first priority in this era of reform. Only with sincerity and courage from all parties will we be able to completely eliminate these dirty practices. ${ }^{44}$

Although the text of the Final Note from the ABK Faction did not explicitly state that such project racketeering practices had occurred in the province of Banten, and did not directly accuse any specific institutions or actors involved in this constellation, this oral and written statement from the ABK Faction served as the trigger factor for further discussion of the project racketeering issue within the DPRD building, which later developed into a topic for public consumption. Just one day after the ABK Faction presented its Final Note in the plenary session of the Banten Provincial DPRD, discussion of the practices of project racketeering spread to outside the DPRD building, and a polemic in the mass media between Tuan Besar and the ABK Faction was unavoidable.

On 27 August 2003 Fajar Banten, one of Banten's leading newspapers, carried a report with the headline 'Tuan Besar denies existence of project racketeering'. Tuan Besar was reported as saying that the accusations of project racketeering put forward by the ABK Faction were defamatory. The

44 This quotation was excerpted from the text of the Final Note of the Mandate-Star-Justice Faction of the DPRD Banten on governor's Financial Note on Revision of the 2003 Regional Budget (Serang, 26 August 2003). The writer has a photocopy of this text. 
statement by the ABK Faction was destructive toward Banten, he continued, and a deviation from Banten's religious culture. Tuan Besar went on to say that the allegations were equivalent to an accusation that all business operators in Banten were guilty of it:

The statement by the ABK Faction about Project Racketeering will not only divide the community, but will also have the effect of destroying Banten's religious culture. Base accusations such as this will only lead to slander, injustice, and slaughter of the charisma and aims of the community of Banten. Such members of the Assembly (who launched this statement) are unsuited to serve as representatives of the public. Actually, if there is anything lacking in the implementation of development in Banten, (this can) be improved collectively, and if there are any deviations, these can be straightened out through consultation. (Fajar Banten 27-8-2003.)

While Tuan Besar and his group were attempting to create a counter-opinion movement regarding project racketeering, support for the ABK Faction continued to flow in. On 28 August 2003 five members of the Presidium for a Clean Community (PCC) visited the Banten Provincial DPRD to declare their support for the ABK Faction. The PCC declared their readiness to work with the ABK Faction to resolve the cases of project racketeering through legal channels. The PCC advised the ABK Faction to submit its evidence to the prosecutor's office and the police (Fajar Banten 28-8-2003).

The polemic about project racketeering heated up when Tuan Besar said that the members of the Banten Provincial DPRD were like 'thieves shouting thief':

We would like to ask the members of the assembly, specifically from the ABK Faction, to point out exactly who they are referring to as (project) racketeers. I see something very odd here: Thieves shouting thief. [...] We have evidence that certain individuals in the legislature (members of the Banten Provincial DPRD) have requested projects from project leaders or from professional associations and organizations. (Fajar Banten 3-9-2003.)

The polemic reached its culmination on 9 September 2003, when Tuan Besar, together with around 100 other Banten business operators, came to the Banten Provincial DPRD building to hold a dialogue with the DPRD members, and specifically with the members from the ABK Faction (Fajar Banten 4-9-2003). The business operators asked the ABK Faction to show concrete evidence about the existence of project racketeering practices, and to state directly exactly which business operators were involved. They demanded that the ABK Faction withdraw its statement, which they felt had created unrest among the business community and the public. The ABK Faction was asked to make a public apology, to be carried in all the local mass media. If they did not comply, the business operators would go through the estab- 
lished legal channels.

But this dialogue, which went on for around two and a half hours, did not attain the desired results, because the ABK Faction managed to avoid a confrontational stance. It said that 'as an extension of the political parties, we cannot comply with the business operators' demand that the ABK Faction withdraw its statement. We will provide a reply as soon as we have held meetings with the political parties'. This was a sensible response, given the increasing 'heat' of the dialogue within the DPRD building and the presence of a large number of pendekar, both inside and outside the building. A report in Fajar Banten (4-9-2003), said that there were around 50 black-uniformed pendekar Banten gathered outside the Banten Provincial DPRD building at the time.

Next, Bueti Nasir (a member of the ABK Faction from the PBB) said that the ABK Faction would not withdraw the statement it had made about project racketeering. Racketeering (premanisme politik) was a relatively polite expression compared with other words with the same general meaning. A similar statement was made by Partai Keadilan Sejahtera (PKS, Banten Justice and Prosperity Party), which said, 'there is no way that the parties will approve the ABK Faction's apologizing and withdrawing its statement about project racketeering, because the statement did not point to anyone (specific institutions or individuals)' (Fajar Banten 5-9-2003).

These indirect replies from the ABK Faction brought a strong reaction from Tuan Besar specifically and from Banten entrepreneurs in general. The Banten Chamber of Commerce and Industry (Kadin) issued a 'Summons' (somasi) to the ABK Faction through letter no. 149/Kadin-Banten/IX/2003 dated 7 September 2003. The basis given for issuing this Summons was that the term 'project racketeering' implies that unethical practices are used by business operators in Banten to win projects. On this basis, the Summons explicitly demanded that the ABK Faction withdraw its statement about project racketeering and apologize to Kadin and to the public of Banten. If the ABK Faction ignored this demand, the Banten Kadin threatened to report the problem to the police (Fajar Banten 8-9-2003).

Responding to this threat, the Chairman of the ABK Faction (Mudjahid Chudori) stated that his side was 'not afraid of the Banten Kadin's threat to report this to the police' (Fajar Banten 8-9-2003). The ABK Faction had solid evidence and enjoyed broad support from various parties. After this the polemic faded away. Apparently, it was difficult for the hopes of Banten's public for a thorough investigation to be realized through the ABK Faction. Numerous technical and political obstacles stalled any resolution of the case through legal channels. As noted by HOS (a member of the ABK Faction), ${ }^{45}$ even though their Faction had sufficient evidence, to follow up on this through 
legal channels they would really need support from the regional executive, and specifically from the governor. But, HOS continued, they did not obtain this support, even though HOS himself tried to persuade the governor.

For myself, at the end of my field research in Banten, I was left with two questions. Why was the ABK Faction never willing to show or reveal its evidence of project racketeering practices committed by Tuan Besar and his group? And why didn't the governor of Banten give his crucially necessary support to the ABK Faction?

\section{Conclusion}

Some academics have responded to situations such as those described in this chapter by suggesting re-centralization of power in the hands of the central government. Such suggestions overlook the fact that not all the problems in the regions are the result of decentralization and regional autonomy policies. It is more accurate to see them as a consequence of the shift in patterns of interaction between state and society in the post-Suharto era. The public (society) is no longer totally marginalized, either in the decision-making process or in implementation. However, this does not mean that we are now living in a fully civil society, for society is represented mostly by the elite. Decision-making at both the national and the local levels is coloured by coalitions and bargaining of interests between the societal and state actors.

The case of project racketeering in the province of Banten demonstrates that the conduct of regional government is far more complex than has been portrayed in the literature to date. Decision-making and policy implementation in the regions are now flavoured with 'collusion' and bargaining of interests among the local government executive elite and the jawara-entrepreneurs. If this empirical reality is related to the shift in patterns of state-society interactions, as mentioned above, then the Banten case shows that post-Suharto decentralization and regional autonomy has created greater space for societal elites to build and develop informal networks with local state actors. Can the operation of these informal networks be considered practices of a 'Shadow State'? The project racketeering occurred together with a weakness in the formal institutions of local government in Banten. This resembles what William Reno (1995) has referred to as a 'Shadow State'. The governor and deputy governor faced great difficulty in getting the formal institutions of the local government to function properly, partly because Tuan Besar, as the main figure in the Shadow State, played a role as financial and political sponsor in getting these two top leaders elected. Tuan Besar's dominant influence over the conduct of local government represents the 'costs in return' for the political and economic investment he made at the time of the election. 